\title{
EVALUATION OF A $4 \pi$ NEUTRON COUNTER FOR THE NONDESTRUCTIVE ANALYSIS OF URANIUM-234 IN URANIUM HEXAFLUORIDE
}

W. T. Mullins

Isotopic Analysis Department

Laboratory Division 


\section{DISCLAIMER}

This report was prepared as an account of work sponsored by an agency of the United States Government. Neither the United States Government nor any agency Thereof, nor any of their employees, makes any warranty, express or implied, or assumes any legal liability or responsibility for the accuracy, completeness, or usefulness of any information, apparatus, product, or process disclosed, or represents that its use would not infringe privately owned rights. Reference herein to any specific commercial product, process, or service by trade name, trademark, manufacturer, or otherwise does not necessarily constitute or imply its endorsement, recommendation, or favoring by the United States Government or any agency thereof. The views and opinions of authors expressed herein do not necessarily state or reflect those of the United States Government or any agency thereof. 


\section{DISCLAIMER}

Portions of this document may be illegible in electronic image products. Images are produced from the best available original document. 
Printed in the United States of America. Available from National Technical Information Service

U.S. Department of Commerce

5285 Port Royal Road, Springfield, Virginia 22161

Price: Printed Copy $\$ 8.50$; Microfiche $\$ 2.25$

This report was prepared as an account of work sponsored by the United States Government. Neither the United States nor the Energy Research and Development Administration, nor any of their employees, nor any of their contractors, subcontractors, or their employees, makes any warranty, express or implied, or assumes any legal liability or responsibility for the accuracy, completeness or usefulness of any information, apparatus, product or process disclosed, or represents that its use would not infringe privately owned rights. 


\section{PAGES 1 to 2 WERE INTENTIONALLY LEFT BLANK}


Date of Issue: February 1976

Report Number: $\mathrm{K}-\mathrm{I} 882$

Distribution Category: UC-37,

Instruments

EVALUATION OF A $4 \pi$ NEUTRON COUNTER FOR THE NONDESTRUCTIVE ANALYSIS OF URANIUM-234 IN URANIUM HEXAFLUORIDE

W. T. Mullins

Isotopic Analysis Department

Laboratory Division

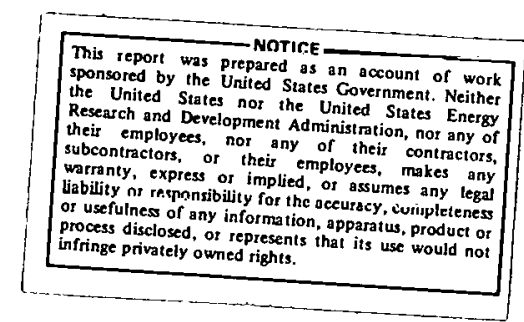

Oak Ridge Gaseous Diffusion Plant

Union Carbide Corporation

Oak Ridge, Tennessee

Prepared for the U.S. Energy Research and Development Administration under U.S. Government Contract W-7405 eng 26

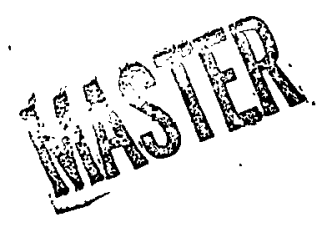


THIS PAGE

\section{WAS INTENTIONALLY LEFT BLANK}




\begin{abstract}
A neutron counter has been evaluated for the nondestructive analysis of uranium-234 in uranium hexafluoride. The instrument was designed by Los Alamos Scientific Laboratory for the Nuclear Safeguards Program.

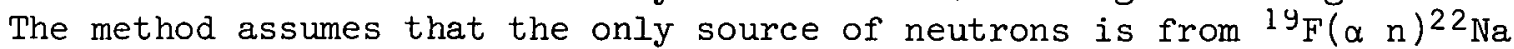
reaction from uranium-238, uranium-235, and uranium-234, the yield from uranium-234 being the most abundant.

This evaluation shows that the mean of the difference between the $4 \pi$ neutron counting method and mass spectrometry is 0.0002 wt \% uranium$234 \pm 0.00015$ at the $95 \%$ confidence level. However, the presence of uranium-232 produces significant errors in the system. If the neutron technique is to be used for samples containing uranium-232 in equilibrium with its daughters, the $2.61-\mathrm{MeV}$ gamma peak of thallium-208 must be measured and used to correct for the uranium-232.

It has been postulated that the neutron counter might also be used to relate the uranium-234 content of a sample to the uranium-235, thus estimating the uranium-235 concentration. This evaluation notes, however, that in a variety of uranium feeds and enriched product, the uranium-234/ uranium-235 ratio varies too widely to enable a valid uranium-?.35 determination.
\end{abstract}




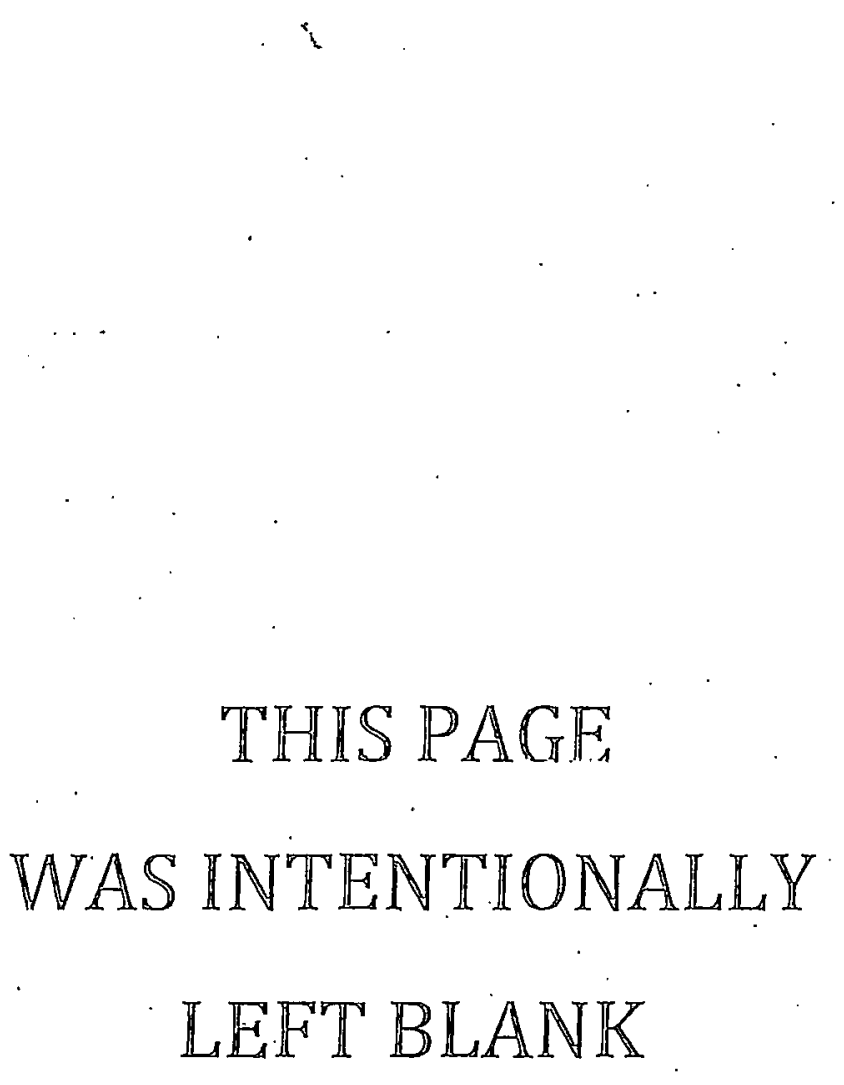


CONTENTS

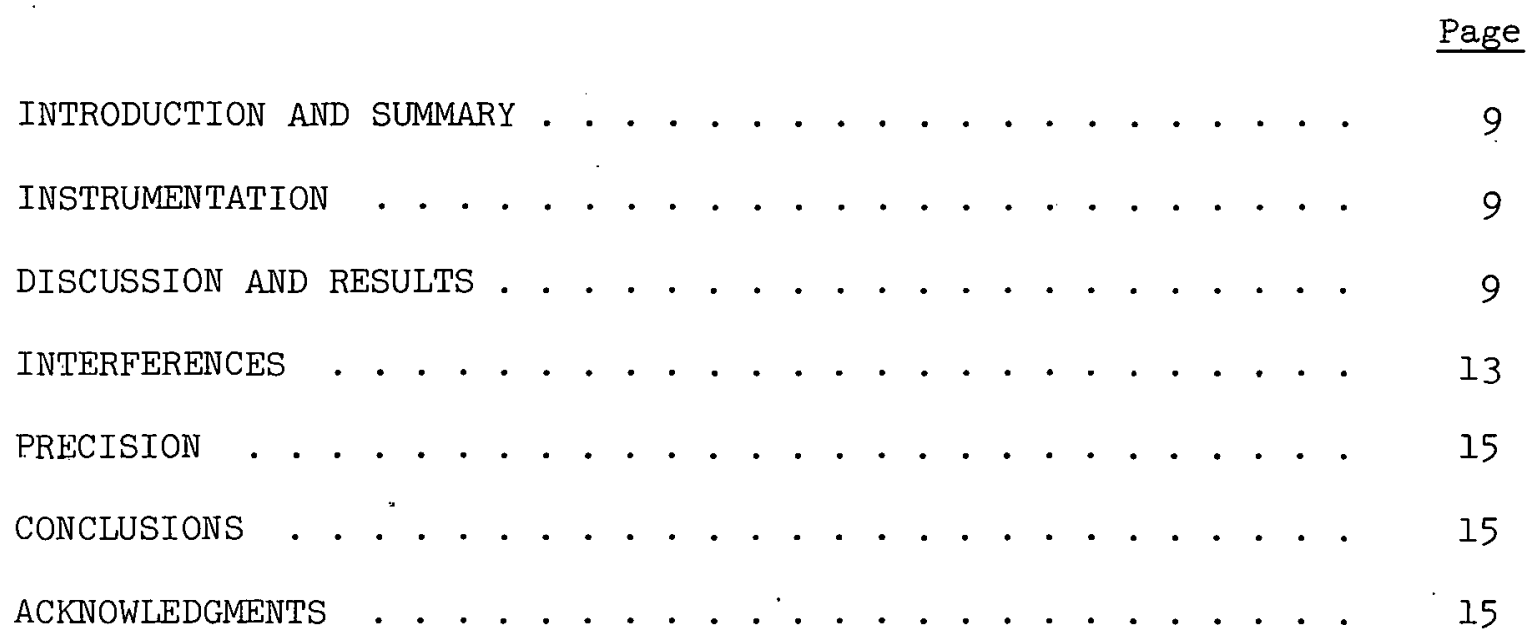




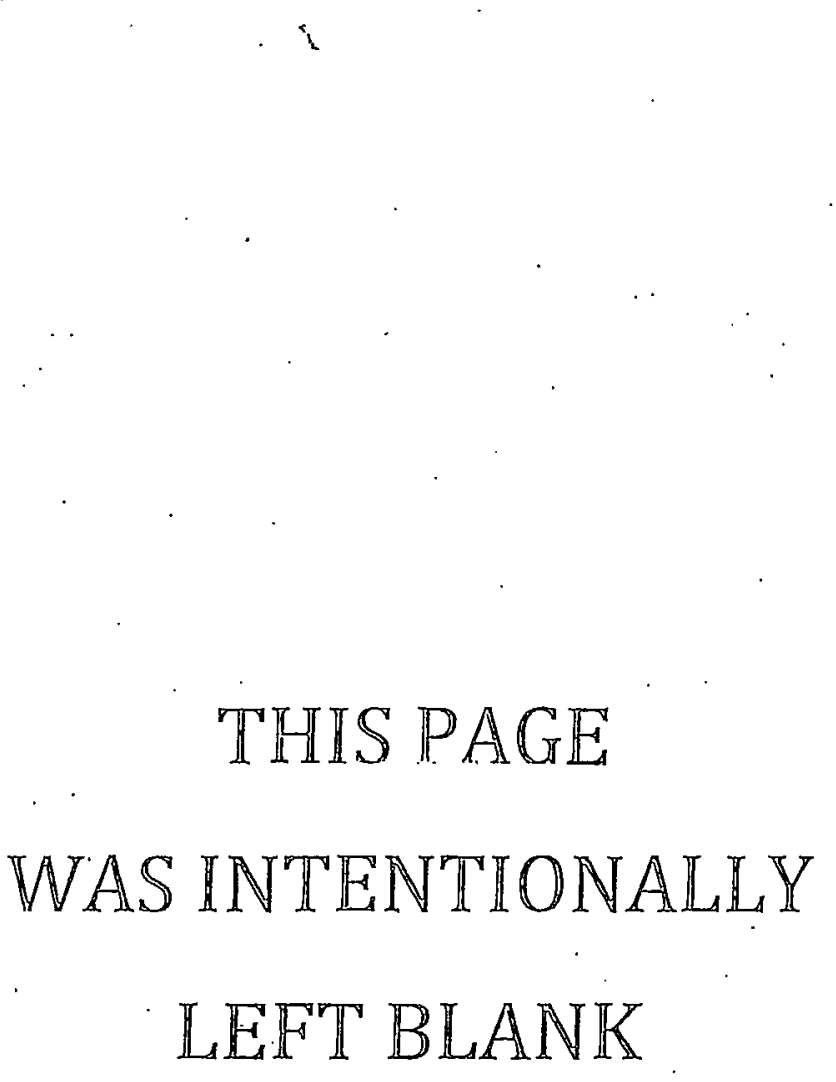


\begin{tabular}{l} 
EVALUATION OF A $4 \pi$ NEUTRON COUNTER FOR THE NONDESTRUCTIVE \\
ANALYSIS OF URANIUM-234 IN URANIUM HEXAFLUORIDE \\
\hline
\end{tabular}

INTRODUCTION · AND SUMMARY

The neutron counter was set up at the Oak Ridge Gaseous Diffusion Plant (ORGDP) for the purpose of evaluating it in an independent measurement of uranium-234 in uranium hexafluoride $\left(\mathrm{UF}_{6}\right)$ from an experiment in the Minor Isotopes Safeguards Technique (MIST).

Sixteen 2S cylinders from the MIST test containing UF $_{6}$ that had been routinely analyzed for uranium-234 and uranium-235 by mass spectrometry were measured in the neutron counter. One cylinder was measured 17 times to establish the precision for the instrument. Each cylinder was measured for 1000 sec, followed by a"1000-sec background count. The counts averaged between 25,000 and 45,000 counts for $1000 \mathrm{sec}$, and the background ranged from 450 to 750 counts for the same counting period. Each 25 cylinder contained approximately $1700 \mathrm{~g}$ of $\mathrm{UF}_{6}$.

\section{INSTRUMENTATION}

The detector consists of fourteen helium-3 tubes, embedded in a polyethylene cylinder (60 $\mathrm{cm}$ in diameter by $79 \mathrm{~cm}$ in height) approximately the size of a 55-gal drum. A well inside the detector assembly will accept IS and $2 S$ cylinders. A IS cylinder is $4 \mathrm{~cm}$ in diameter, and has a fill limit of $454 \mathrm{~g}$ of $\mathrm{UF}_{6}$, whereas a $2 \mathrm{~S}$ cylinder is $9 \mathrm{~cm}$ in diameter and has a fill limit of $2225 \mathrm{~g}$ of $\mathrm{UF}_{6}$ (see Figure 1 ).

\section{DISCUSSION AND RESULTS}

The uranium-234 analysis is derived from a background-corrected neutron count, using the expression

$$
\text { Wt \% Uranium-234 = aS }-b, *
$$

where :

$\mathrm{S}$ is the number of neutrons for $1000 \mathrm{sec} / \mathrm{g} \mathrm{UF} 6$ and the constants, $a$ and $b$, are obtained from a best fit curve of plotted mas's suectrometer data.

*Stieff, L. R., Walton, R. B., Reilly, T. D., Fields, L. W., Walker, R. L., Mullins, W. T., and Thoms, J. I., Neutron Measurements of U-234 Isotopic Abundances in $U F_{6}$ Samples, orally presented at the Institute of Nuclear Materials Management. Meeting at New Orleans, Louisiana, June 1975. 


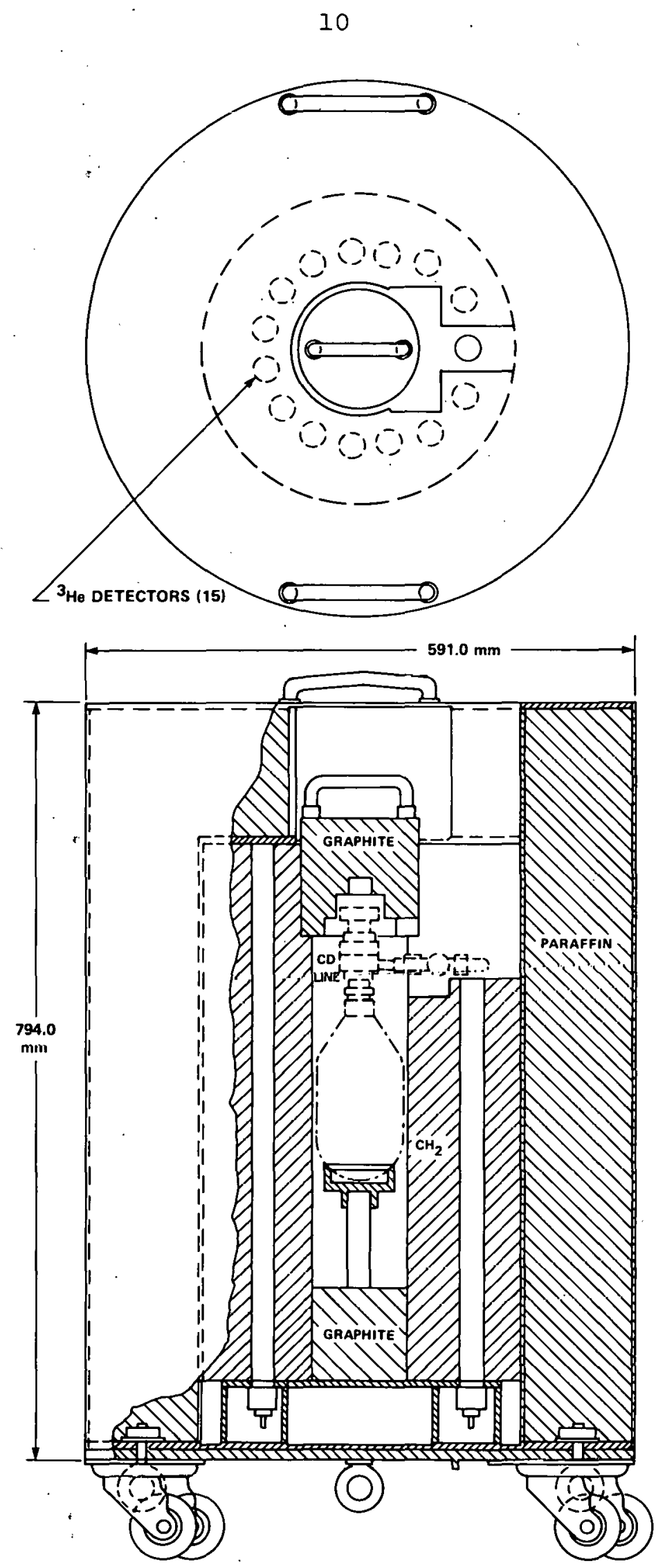

DWG. NO. 6-76-1

(U) 
This expression assumes that there are three sources of neutrons: uranium-234 (the most dominant in enriched uranium), uranium-235, and uranium-238 from the ${ }^{19} \mathrm{~F}(\alpha \mathrm{n})^{22} \mathrm{Na}$ reaction. Table 1 lists the neutron yields from the fluorides of the uranium isotopes.

$$
\text { Table } 1(a)
$$

$(\alpha \mathrm{n})$ YIELDS FROM FLUORIDES

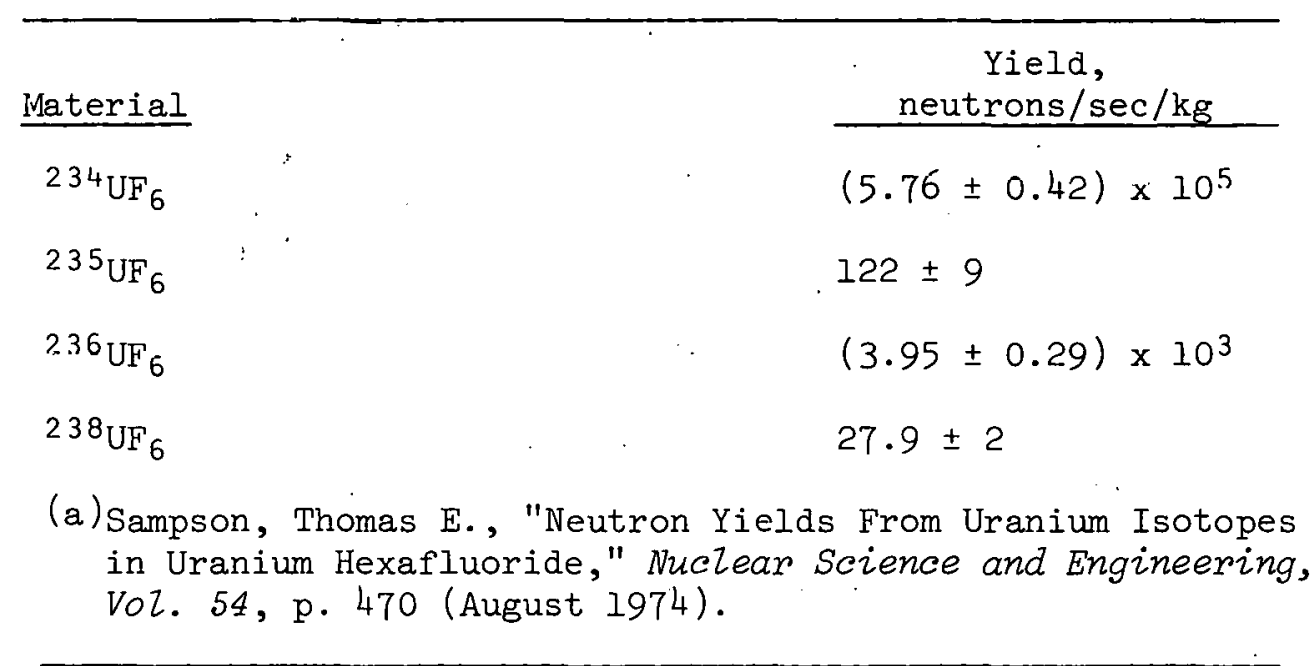

It is estimated that the neutron yield per $\mathrm{kg}$ for uranium-232, without its daughters, is $3 \times 10^{9}$.* In equilibrium with its daughters, the neutron yield would be increased by a factor of 5 .

Sixteen $2 S$ cylinders containing $U_{6}$ that had been routinely analyzed for uranium-234 and uranium-235 by mass spectrometry were obtained and medsured in the neutiron counter. Five cylinders were selected for use as standards. The $\mathrm{UF}_{6}$ from three cylinders was redidyzed for wt $\%$ uraniurl-234 at ORGDP, and $\mathrm{UF}_{6}$ samples from five cylinders were analyzed at the Oak Ridge National Laboratory (ORNL). Table 2 shows the results. The averages of the wt \% uranium-234 results from ORGDP and ORNL analyses were used to determine the $a$ and $b$ constants. The following equation was used to calculate the wt \% uranium-234 by the neutron measurement:

$$
\text { Wt \% Uranium-234 }=0.001347 \mathrm{~s}-0.004212
$$

Table 3 shows the results.

*Stieft, L. R., et al., Zoc. eit. 
Table 2

WEIGHT PERCENT URANIUM-234 BY MASS SPECTROMETRY AT ORGDP AND ORNL

\begin{tabular}{|c|c|c|c|c|c|}
\hline $\begin{array}{c}\text { Cylinder } \\
\text { No. }\end{array}$ & 210957 & 210967 & 964908 & 210913 & 210952 \\
\hline \multirow[t]{5}{*}{ ORGDP: } & 0.02175 & 0.03194 & 0.01547 & & \\
\hline & 0.02179 & 0.03151 & 0.01514 & & \\
\hline & 0.02190 & 0.03148 & 0.01525 & & \\
\hline & 0.02192 & 0.03136 & 0.01522 & & \\
\hline & & & 0.01522 & & \\
\hline Average & 0.02184 & 0.03157 & 0.01526 & & \\
\hline ORNL: & 0.02156 & 0.03112 & 0.01552 & 0.01716 & 0.02748 \\
\hline Best Value & 0.02170 & 0.03134 & 0.01539 & 0.01716 & 0.02748 \\
\hline
\end{tabular}

The precision for a single measurement of the ORGDP results is \pm 0.00048 , at the $95 \%$ confidence level. The ORNL results are reported to be \pm 0.0001 .

Table 3

WEIGHT PERCENT URANIUM-234 BY MASS SPECTROMFTRY AIND $4 \pi$ NËUTRON ANALYSIS

\begin{tabular}{|c|c|c|c|c|c|}
\hline $\begin{array}{l}\text { Cylinder } \\
\text { No. } \\
\end{array}$ & $\begin{array}{c}\mathrm{S} \\
\mathrm{n} / 1000 \mathrm{sec} \\
\text { per }^{i} \mathrm{~g} \quad \mathrm{UF}_{6} \\
\end{array}$ & $\begin{array}{c}\text { Wt \% } \\
\text { Uranium-234 } \\
\text { Neutron } \\
\text { Analysis (N) }\end{array}$ & $\begin{array}{c}\text { Wt \% } \\
\text { Uranium-234 } \\
\text { Mass } \\
\text { Spectrometry (MS) } \\
\end{array}$ & & $\mathrm{MS}-\mathrm{N}$ \\
\hline 210951 & 23.24 & 0.027 & 0.028 & & 0.001 \\
\hline 210959 & 18.86 & 0.021 & 0.022 & & 0.001 \\
\hline 4.90060 & 21.32 & 0.024 & 0.023 & & $-0.00 i$ \\
\hline 210968 & 26.07 & 0.031 & 0.031 & & 0 \\
\hline 964904 & 25.35 & 0.030 & 0.031 & & 0.001 \\
\hline 964905 & 24.94 & 0.029 & 0.029 & & 0 \\
\hline 210958 & 19.14 & 0.022 & 0.022 & & 0 \\
\hline 210961 & 19.38 & 0.022 & 0.023 & & 0.001 \\
\hline \multirow[t]{2}{*}{210966} & 26.36 & 0.031 & 0.030 & & -0.001 \\
\hline & & & & $\overline{\mathrm{X}}$ & 0.0002 \\
\hline
\end{tabular}


Note from Table 3 , the mean of the difference between the two measurements is 0.0002 wt $\%$ uranium-234 \pm 0.00015 at the $95 \%$ confidence level.

\section{INTERFERENCES}

The method assumes that since the neutron yield from uranium-234 is the most abundant, the method is relatively insensitive to changes in the uranium-234/uranium-235 ratio. The analyses of wt.\% uranium-234 and wt \% uranium-235 in $438 \mathrm{UF}_{6}$ samples were reviewed, and Table 4 shows fluctuations typical of the uranium-234 to uranium-235 ratios.

Table 4

VARIATION OF URANIUM-234 IN URANIUM HEXAFLUORIDE

\begin{tabular}{|c|c|c|c|c|c|}
\hline \multirow[b]{2}{*}{ Material. } & \multicolumn{3}{|c|}{$\begin{array}{l}\text { Uranium-234/Uranium-235 } \\
\text { Ratio Range }\end{array}$} & \multirow{2}{*}{$\begin{array}{l}\text { High/ } \\
\text { Low }\end{array}$} & \multirow{2}{*}{$\begin{array}{l}\text { No. of } \\
\text { Samples }\end{array}$} \\
\hline & Mean & High & Low & & \\
\hline $\begin{array}{l}\text { Reactor Processed } \\
\text { Feed }\end{array}$ & 0.00814 & 0.01201 & 0.00467 & 2.572 & 96 \\
\hline $\begin{array}{l}>3 \text { wt } \% \text { Uranium- } \\
235 \text { Product }\end{array}$ & 0.00873 & 0.00954 & 0.00736 & 1.296 & 193 \\
\hline $\begin{array}{l}2.4 \text { to } 2.8 \text { wt } \% \\
\text { Uranium-235 } \\
\text { Product }\end{array}$ & 0.0 .0836 & 0.0133 & $0.0067 ?$ & 1.979 & 149 \\
\hline
\end{tabular}

Note from Table 4 the fluctuations of the uranium-234 ton uranium-235. ratio in an extreme case can vary as much as 2.57 times. If this procedure is used to determine uranium-234 as a measure of the uranium-235, an error can be as large as 52\% of the uranium-235 value.

Uranium-232, sometimes found in reactor-processed uranium, also interferes in this procedure. Two cylinders containing uranium-232 were analyzed by the neutron method. Table 5 shows the results. 
Table 5

\section{VARIATION OF URANIUM-232 IN REACTOR-PROCESSED URANIUM}

\begin{tabular}{|c|c|c|c|c|}
\hline Material & ppb $\frac{\text { Uranium-232 }}{\text { Uranium-235 }}$ & $\begin{array}{c}\text { Wt } \% \\
\text { Uranium-234, } \\
\text { Neutron (N) }\end{array}$ & $\begin{array}{c}\text { Wt } \% \\
\text { Uranium-234, } \\
\text { Mass } \\
\text { Spectrometry } \\
\text { (MS) } \\
\end{array}$ & $\frac{N-M S}{M}, \%$ \\
\hline 490044 & 54 & 0.019 & 0.015 & 27 \\
\hline 490045 & 29 & 0.013 & 0.011 & 18 \\
\hline
\end{tabular}

Note that by the neutron method, only $29 \mathrm{ppb}$ of uranium-23/uranium-235 will cause the wt \% uranium-234 measurement to be erroneously high by $18 \%$.

Using the neutron yields in Table 1 , and assuming a UF 6 sample enriched to 1.5 wt \% uranium-235, containing $0.015 \%$ uranium-234 and 54 ppb uranium232/uranium-235, the calculations in Table 6 indicate that the uranium232 produces $12 \%$ of the total number of neutrons.

Table 6

URANIUM-232 CALCULATED IN REACTOR-PROCESSED URANIUM

\begin{tabular}{|c|c|c|c|c|c|}
\hline $\begin{array}{l}\text { Uranium } \\
\text { Isotope }\end{array}$ & & $\begin{array}{c}\% \text { Uranium } \\
\text { Isotope } \\
\end{array}$ & $\begin{array}{c}\text { Neutron } \\
\text { Yield }\end{array}$ & $\begin{array}{c}\text { No. } \\
\text { Neutrons } \\
\end{array}$ & $\begin{array}{l}\% \text { of } \\
\text { Total }\end{array}$ \\
\hline Uranium-238 & $\cdot$ & 98.49 & 27.9 & 2748 & 20.83 \\
\hline Uranium-23̣5 & & 1.50 & 122 & 183 & 1.39 \\
\hline Uranium-234 & & 0.015 & $5.76 \times 10^{5}$ & $8.64 \times 10^{3}$ & 65.50 \\
\hline Uranium-232 & & $5.4 \times 10^{-7}$ & $3 \times 10^{9(a)}$ & $1.62 \times 10^{3}$ & 12.28 \\
\hline
\end{tabular}

If the urarium-232 is in equilibrium with its daughter thallium-208, the $2.61 \mathrm{MeV}$ of thallium-208 can be measured by gamma spectrometry, and used to correct the uranium-234 analysis. 


\section{PRECISION}

In order to check the precision of the instrument, one cylinder (490045) was measured 17 times over a period of several days. Table 7 shows the results.

Table 7

COUNTS/GRAM OF URANIUM HEXAFLUORIDE FOR 1000 SECONDS

\begin{tabular}{lcr}
\hline 12.93 & 13.15 & 12.93 \\
13.09 & 12.92 & 13.06 \\
12.93 & 13.07 & 12.96 \\
12.85 & 12.82 & 12.95 \\
12.89 & 12.96 & 13.00 \\
13.00 & 13.00 & - \\
The mean of these measurements is $12.97 \pm 0.045$ at the $95 \%$ con- \\
fidence level.
\end{tabular}

CONCLUSIONS

It is concluded from this evaluation that a $4 \pi$ neutron counter provides a fast, nondestructive method for the analysis of uranium-234 with good precision. From a study of nine $2 S$ cylinders of $U_{6}$, the mean of the differenre between the $4 \pi$ neutron method and mass spectrometry is 0.0002 wt \% uranium-234 \pm 0.00015 at the $93 \%$ confldence level.

Two serious errors can affect the procedure, unless one applies some prior knowledge of the history of the sample, or makes supplementary corrective analyses. First, if the procedure is to be used to determine uranium-234 as a measure of the uranium-235, then as has been pointed out from Table 5, it is possible for the uranium-234/uranium-235 ratio to vary as much as 2.57 times and cause an error as large as $52 \%$. From Table 6, it is also shown that the presence of uranium-232 as low as 29 $\mathrm{ppb}$ (on a uranium-235 basis) can cause an error as large as 18\% in the uranium-234 analysis.

\section{ACKNOWLEDGMENTS}

The author is appreciative of the statictical evaluation of J. M. Gerwels of the Barrier and Materials Evaluation Department of the Laboratory Division. 


\section{THIS PAGE}

WAS INTENTIONALLY

LEFT BLANK 
DISTRIBUTION

\section{INTERNAL}

1- 3. Laboratory Division

$$
\begin{aligned}
& \text { Barton, J. C. } \\
& \text { Mullins, W. T. } \\
& \text { Smith, L. A. }
\end{aligned}
$$

4- 5. Library

6. Operations Division Legeay, A. J.

7. Technical Director Wilcox, W. J., Jr.

8- 9. ORGDP Records Department (RC)

10-11. Goodyear Atomic Corporation Spring, H. S. Voss, F. S.

12-13. Paducah

$$
\begin{aligned}
& \text { Beverly, C. R. } \\
& \text { Levin, R. W. }
\end{aligned}
$$

14-15. Y-12 Plant

$$
\begin{aligned}
& \text { Griffin, J. D. } \\
& \text { Zerby, C. D. }
\end{aligned}
$$

EXTERNAL

16. Los Alamos Scientific Laboratory

$$
\text { Walton, R. B. }
$$

17. U.S. Arms Control and Disarmament Agency Stieff, L. R.

18-185. TID-4500, UC-37 